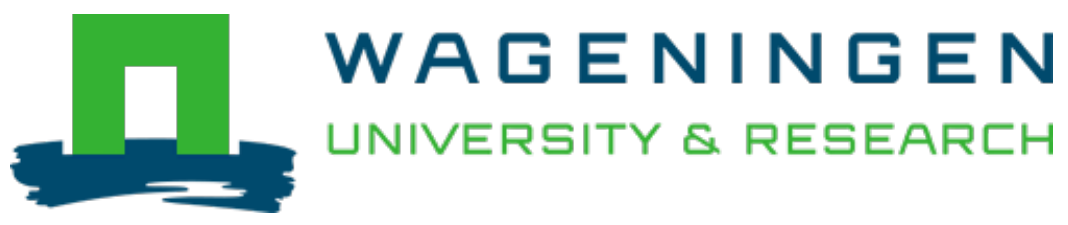

\title{
Farmers' beliefs and voluntary vaccination schemes: Bluetongue in Dutch dairy cattle
}

\author{
Food Policy \\ Sok, J.; Hogeveen, H.; Elbers, A.R.W.; Oude Lansink, A.G.J.M. \\ https://doi.org/10.1016/j.foodpol.2015.09.006
}

This article is made publicly available in the institutional repository of Wageningen University and Research, under the terms of article $25 \mathrm{fa}$ of the Dutch Copyright Act, also known as the Amendment Taverne. This has been done with explicit consent by the author.

Article 25 fa states that the author of a short scientific work funded either wholly or partially by Dutch public funds is entitled to make that work publicly available for no consideration following a reasonable period of time after the work was first published, provided that clear reference is made to the source of the first publication of the work.

This publication is distributed under The Association of Universities in the Netherlands (VSNU) 'Article $25 \mathrm{fa}$ implementation' project. In this project research outputs of researchers employed by Dutch Universities that comply with the legal requirements of Article $25 \mathrm{fa}$ of the Dutch Copyright Act are distributed online and free of cost or other barriers in institutional repositories. Research outputs are distributed six months after their first online publication in the original published version and with proper attribution to the source of the original publication.

You are permitted to download and use the publication for personal purposes. All rights remain with the author(s) and / or copyright owner(s) of this work. Any use of the publication or parts of it other than authorised under article $25 \mathrm{fa}$ of the Dutch Copyright act is prohibited. Wageningen University \& Research and the author(s) of this publication shall not be held responsible or liable for any damages resulting from your (re)use of this publication.

For questions regarding the public availability of this article please contact openscience.library@,wur.nl 


\title{
Farmers' beliefs and voluntary vaccination schemes: Bluetongue in Dutch dairy cattle
}

\author{
J. Sok ${ }^{a}, *$, H. Hogeveen ${ }^{a}$, A.R.W. Elbers ${ }^{b}$, A.G.J.M. Oude Lansink ${ }^{a}$ \\ ${ }^{a}$ Department of Social Sciences, Business Economics, Wageningen University, Hollandseweg 1, NL-6706 KN Wageningen, The Netherlands \\ ${ }^{\mathrm{b}}$ Department of Epidemiology, Crisis Organisation and Diagnostics, Central Veterinary Institute (CVI) of Wageningen UR, P.O. Box 65, NL-8200 AB Lelystad, The Netherlands
}

\section{A R T I C L E I N F O}

\section{Article history:}

Received 4 February 2015

Received in revised form 11 September

2015

Accepted 30 September 2015

\section{Keywords:}

Farmers

Decision-making

Beliefs

Disease control

Bluetongue

Voluntary schemes

Policy instruments

\begin{abstract}
A B S T R A C T
Background: This research utilizes the Reasoned Action Approach framework to study which beliefs drive the intention of farmers to participate in a voluntary vaccination scheme against Bluetongue.

Scope and approach: Knowing the driving beliefs can help in selecting an appropriate mix of policy instruments to enhance the participation rate and thereby improve the cost-effectiveness and efficiency of voluntary vaccination strategies. Results are used to evaluate the policy instruments used by the Dutch government in their 2008 vaccination strategy (communicative intervention and vaccine subsidization). Key findings and conclusions: The paper posits that social interaction mechanisms, such as peer group pressure, might advance the design of voluntary vaccination strategies.
\end{abstract}

(c) 2015 Elsevier Ltd. All rights reserved.

\section{Introduction}

Voluntary schemes are increasingly used in the governance of a secure and safe supply of food. For many issues, such as the veterinary and (phyto)sanitary safety, the governance is shifting in the direction of a more neoliberal model of cost and responsibility sharing (e.g. Enticott et al., 2014; Maye et al., 2014). Economic theory postulates that self-regulation may result in successful interventions at lower public cost (e.g. Oude Lansink, 2011). The ex-ante transaction costs of lobbying and legislation and ex-post transaction costs of surveillance and enforcement are minimized (Furubotn and Richter, 1998).

Regarding veterinary safety, governments worldwide agree on controlling animal diseases listed by the World Organisation of Animal Health (OIE) (OIE, 2014). In 2006, the Netherlands was struck by an introduction of Bluetongue (BT), one of such OIE-listed diseases. Given her international responsibilities, the Dutch Ministry installed a package of disease prevention and control measures appropriate for BT (European Council, 2000, 2007). A mass transnational vaccination scheme with a vaccine made available from Spring 2008 onwards, was needed to control the disease (Sok et al., 2014; Velthuis et al., 2011).

\footnotetext{
* Corresponding author. Tel.: +31 317 485154; fax: +31 317482745

E-mail address: jaap.sok@wur.nl (J. Sok).
}

Most European member states opted for a mandatory vaccination scheme, whereas the Netherlands, amongst a few others, opted for a voluntary approach. Two types of policy instruments were deployed to stimulate voluntary participation by farmers. A communicative intervention was implemented in which the Ministry as well as farmer organizations conveyed written or oral recommendations to motivate farmers intrinsically to vaccinate their cattle. Subsidization of the vaccination costs as an extrinsic motivator was another policy instrument put in place (Ministry of Economic Affairs, 2008).

The vaccination scheme, together with the standard prevention and control measures at EU level, was successful as the total number of reported outbreaks in the EU dropped from 45,000 in 2008 to 1118 in 2009, to 176 in 2010, and finally to 39 in 2011 (IFAH, 2012). In the Netherlands, only 66 outbreaks were reported in 2008 compared to more than 6500 in 2007 (Elbers et al., 2009). Accordingly, the voluntary approach was sufficiently effective in controlling the spread from an epidemiological viewpoint. However, it must be noted that the average seroprevalence of antibodies against the BT virus among dairy cattle was already 68\% before the vaccination scheme started (Ministry of Economic Affairs, 2008) while it was estimated that approximately $80 \%$ of livestock with protecting antibodies - required either by infection or immunization - was probably needed to prevent between-herd transmission (de Koeijer et al., 2011). 


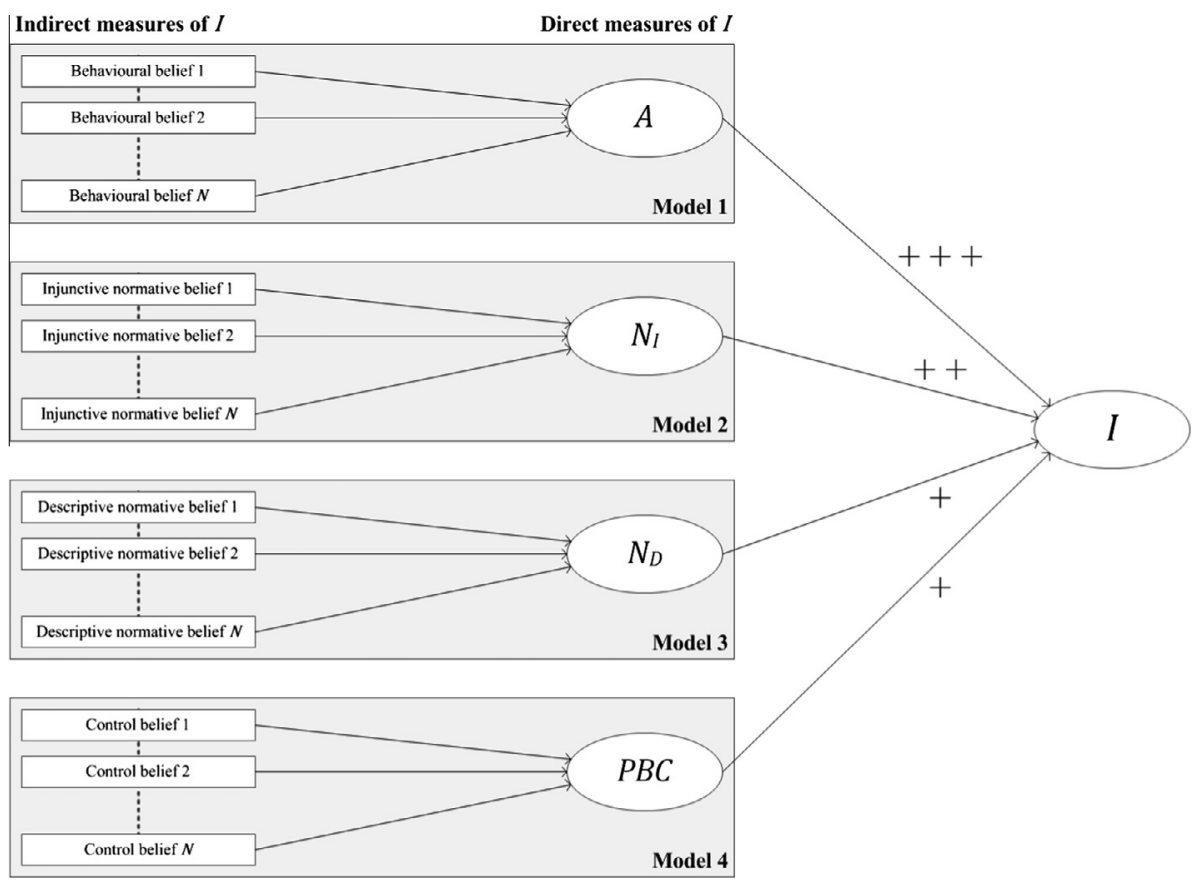

Fig. 1. Framework based on the Reasoned Action Approach (RAA). The number of plusses indicate the relative importance of each construct on intention.

The epidemiological effectiveness of the voluntary approach depends on the level of participation of farmers in the vaccination scheme. The higher the level of participation, the more likely it becomes that the necessary level of immunological protection is reached that is required to disrupt the epidemic spread. As a consequence, also the cost effectiveness (control of the spread of the disease at the lowest costs possible) and the overall efficiency (costs of the vaccination scheme in relation to the benefits) will depend on the participation of farmers. For the past Dutch BT vaccination scheme, the mean level of participation among cattle farmers in 2008 was estimated at 71\% and at 57\% in 2009 (Elbers et al., 2010).

An exploratory survey among farmers showed that motivation to participate in a voluntary vaccination scheme against BT was driven by economic objectives but also by social-psychological objectives like animal welfare considerations and the perceived need to make a contribution to the eradication campaign (Elbers et al., 2010); these objectives relate to beliefs of farmers. Knowing which beliefs of farmers drive their decision to participate in a voluntary vaccination scheme is important as it can help understanding what kind of policy instruments most likely enhance the level of participation and thereby improve the (cost-)effectiveness and efficiency of voluntary vaccination strategies.

The main contribution of this paper is exploring farmers' beliefs on this subject, as to date they are not well-understood. This study utilizes the Reasoned Action Approach (RAA, Fishbein and Ajzen, 2010). RAA decomposes beliefs into attitudinal, normative and control beliefs. Results are used to evaluate the Netherlands' past BT vaccination strategy and to provide insights that can be used to designing future voluntary vaccination strategies.

\section{Framework}

Fig. 1 presents the conceptual framework based on the Reasoned Action Approach that is used in this paper for analyzing farmers' beliefs. The RAA predicts that a given behaviour $(B)$ is determined by the intention $(I)$ to perform the behaviour. $I$, in turn, is directly explained by four main psychological constructs: attitude $(A)$, the farmers' positive or negative evaluation of performing that behaviour; perceived norms $(P N)$, the social pressures famers perceive to perform that behaviour; and perceived behavioural control $(P B C)$, the perceived own capability to perform that behaviour. Within $P N$, a distinction is made between injunctive norms $\left(N_{I}\right)$, the perceptions of what referents think one should do; and descriptive norms $\left(N_{D}\right)$, the perceived behaviour of others (farmers). All direct measures explaining $I$, in turn, are explained by underlying beliefs, which are the indirect measures explaining $I$.

The abovementioned constructs can be measured either directly or indirectly. Sok et al. $(2015)^{1}$ estimated them with direct measures only. This was done for two reasons (Montaño and Kasprzyk, 2008): (1) direct measures are usually more strongly associated with intentions than indirect measures, and (2) the associations between direct measures and intentions indicate the relative importance of the constructs in predicting a given behaviour.

Results revealed that the farmers' intention to participate in a reactive vaccination scheme against $\mathrm{BT}$ is mainly attitude-driven, however, normative considerations (social pressures) also influenced intention formation, with injunctive norms being more important than descriptive norms (Sok et al., 2015). Given this result, the relative importance of the constructs on $I$ is indicated in Fig. 1 by the number of plusses, with more plusses indicating a greater importance. This implies that attitudinal and injunctive normative beliefs outweigh the descriptive normative and control beliefs (indirect measures).

The next section elaborates on how beliefs are identified and elicited, and subsequently analyzed to find the drivers behind the intention to participate in a voluntary hypothetical reactive vaccination scheme against $B T$.

\section{Materials and methods}

Identification, elication and models for analyzing beliefs

The first step in applying the RAA is the identification and elicitation of farmers' beliefs. For this step, semi-qualitative interviews were held in May/June 2013 with 7 dairy farmers and 1 veterinarian from different parts within the Netherlands. To obtain a set of

\footnotetext{
1 This paper is currently under revision and is part of the same research project. It is based on the same questionnaire that has been used here.
} 
underlying beliefs for each construct, $A, N I, N D$ and $P B C$, each respondent was asked a number of questions. In order to obtain the attitudinal beliefs underlying $A$, interviewees were asked to list the (dis)advantages of performing the behaviour under study. In case of injunctive normative beliefs underlying $N I$, interviewees were asked to list the individuals or groups who would (dis)approve of their performing the behaviour under study. To obtain descriptive normative beliefs underlying $N D$, interviewees were asked to list the individuals or groups for which it was expected that they will perform the behaviour under study. In case of control beliefs underlying $P B C$, interviewees were asked to list factors or circumstances that would make it more easy (difficult) and/or persuade (dissuade) him or her to perform the behaviour under study. All responses from the 7 dairy farmers (and 1 veterinarian) were listed and subsequently analyzed on the main recurring beliefs.

Since there are four main psychological constructs - $A, N I, N D$ and $P B C$ - that can determine $I$, four different models were central (see Fig. 1) for analyzing the main recurring beliefs identified. They can be represented by the following equations:

$A=f\left(b_{i j} e_{i j}\right)$,

where $A$ is the farmer's positive or negative evaluation of performing that behaviour, $b_{i j}$ the strength of the attitudinal belief about attribute $i(i=1,2, \ldots, 5)$ in statement $j(j=1,2)$ and $e_{i}$ the evaluation of attribute $i(i=1,2, \ldots, 5)$ in statement $j(j=1,2)$;

$N_{I}=f\left(i_{k} m_{k}\right)$,

where $N_{I}$ is farmers' perception of what referents think they he or she should do, $i n_{j}$ the injunctive normative belief about referent $k$ $(k=1,2, \ldots, 12)$ and $m_{k}$ the motivation to comply with referent $k$ $(k=1,2, \ldots, 12)$;

$N_{D}=f\left(d n_{l} i_{l}\right)$,

where $N_{D}$ is the perceived behaviour of other farmers, $d n_{l}$ the descriptive normative belief about referent $l(l=1,2, \ldots, 4)$ and $i_{l}$ the identification with referent $l(l=1,2, \ldots, 4)$;

$P B C=f\left(c_{m n} p_{m n}\right)$,

where $P B C$ is the perceived personal capability to perform that behaviour, $c_{m n}$ the belief of the presence of control factor $m$ $(m=1,2, \ldots, 5)$ in statement $n(n=1,2)$ and $p_{m n}$ the power of control factor $m(m=1,2, \ldots, 5)$ in statement $n(n=1,2)$.

In each equation, a multiplicative composite, such as $b_{11} e_{11}$ or $i n_{2} m_{2}$, is the product of a belief with an outcome evaluation, with a possible score ranging from -10 to 10 . Originally, this idea of measurement stems from the expectancy-value model, initially applied to attitude measurement (Feather, 1959; Fishbein, 1963).

\section{Questionnaire and sample}

Table 1 presents the attitudinal belief statements that were incorporated in the questionnaire. Each belief statement was preceded with the phrase: "Were Bluetongue to occur in my environment this year and I was to vaccinate", and measured on a 5-point unipolar ${ }^{2}$ Likert type scale with endpoints from 'Not likely' to 'Very likely'. Each outcome evaluation (evaluation of attribute) statement was preceded with the phrase: "Will the following motives be important if you consider preventive vaccination of your herd if Bluetongue were to occur in your environment this year?", and mea-

\footnotetext{
${ }^{2}$ Whether the measurement scale should be unipolar or bipolar was determined by looking at the nature of the concept measured (e.g. Francis et al., 2004). For example, the attitudinal belief about an attribute can be characterized as a probability, which is a unidirectional concept, and thus a unipolar measurement scale is more appropriate, while for an attribute evaluation a bipolar measurement scale is most realistic.
}

sured on a 5-point bipolar Likert type scale with endpoints from 'Important' to 'Unimportant'.

For each injunctive referent considered in the questionnaire (Table 2), the normative belief statement was formulated as: "What is the opinion of $<$ referent $k>$ about preventive vaccination of your herd if Bluetongue were to occur in your environment this year?", and was measured on a 5-point bipolar Likert type scale with endpoints from 'Strongly against' to 'Highly in favour'. Each outcome evaluation (motivation to comply to referent $k$ ) statement was formulated as: "Is the opinion of $<$ referent $k>$ important to you when considering preventive vaccination of your herd if Bluetongue were to occur in your environment this year?", and was measured on a 5-point unipolar Likert type scale with endpoints from 'Unimportant' to 'Very important'.

For each descriptive referent considered in the questionnaire (Table 3), the normative belief statement was formulated as: 'Is $<$ referent $l>$ going to preventively vaccinate his or her herd if Bluetongue were to occur this year in the environment?', and was measured on a 5-point bipolar Likert type scale with endpoints from 'Definitely not' to 'Definitely'. Each outcome evaluation (identification with referent $l$ ) statement was formulated as: "Is what <referent $l>$ is going to do if Bluetongue were to occur in the environment this year important for your consideration to vaccine your herd preventively?", and was measured on a 5-point unipolar Likert type scale with endpoints from 'Unimportant' to 'Very important'. In both the injunctive and descriptive normative section a 'Not applicable' $(N A)$ option was included.

Table 4 presents the description of the control belief statements that were incorporated in the questionnaire. Each belief statement was preceded with the phrase: "If a voluntary vaccination scheme was to be announced when Bluetongue were to occur in my environment this year", and measured on a 5-point unipolar Likert type scale with endpoints from 'Unlikely' to 'Very likely'. Each outcome evaluation (power of control factor) statement was preceded with the phrase: "Will the following issues make it easier (persuade) or more difficult (dissuade) for you to vaccinate your herd preventively if Bluetongue were to occur in your environment this year?", and measured on a 5-point bipolar Likert type scale with endpoints from 'More difficult/dissuade' to 'Easier/persuade'.

A random sample of 1500 Dutch dairy farms was drawn from the National Cattle Identification and Registration Database. Only farms with a herd size of at least 40 dairy cows were selected, as these are more likely to be professional dairy farmers rather than hobby farmers. Hobby farmers were excluded because their vaccination decisions, in the face of a threat of a Bluetongue infection, involves different arguments that are more likely driven by idealistic motives (Elbers et al., 2010).

The questionnaire was pre-tested with two dairy farmers to check for flaws or problems with interpretation of questions. The final, revised questionnaire, along with a pre-paid return envelope and an accompanying letter, was sent out in the second week of January 2014. Farmers were offered two possibilities to fill in the questionnaire, i.e. using the paper copy, or an on-line survey. Each respondent had a $10 \%$ chance of winning a gift coupon of $€ 25$. After 4 weeks, a reminder was sent to all farmers in the sample. The final response, the 415 th, was returned around mid-March, resulting in a response rate of almost $28 \%$.

\section{Statistical model}

In a related empirical study using the RAA, structural equation modelling (SEM) is applied (Sok et al., 2015). I, $A, N_{I}, N_{D}$ and $P B C$ are represented by a set of correlated effect indicators and analyzed as latent variables, to investigate the presence of causal relations as specified in the RAA. In this study, beliefs (multiplicative composites) will be the causal indicators that have an impact 
Table 1

Description and some descriptive statistics of the attitudinal beliefs identified.

\begin{tabular}{|c|c|c|c|c|c|c|}
\hline Attributes & Ind. & $\begin{array}{l}\text { Attitudinal belief statement } \\
\text { Were Bluetongue to occur in my environment this year and I was to vaccinate... }\end{array}$ & $n$ & corr $^{\mathrm{b}}$ & $\alpha_{C}^{\mathrm{d}}$ & $\mathrm{M}\left(S E_{M}\right)$ \\
\hline \multirow[t]{2}{*}{ 1. Production distortions } & $b e_{11}$ & $\ldots$ will it have to cope with negative side effects and/or stress ${ }^{a}$ & 377 & -0.17 & 0.33 & $1.15(4.41)$ \\
\hline & $b e_{12}$ & $\begin{array}{l}\text {... will vaccination negatively influence the physical condition and } \\
\text { performance of my herd }\end{array}$ & 377 & $0.08^{c}$ & & $2.12(4.19)$ \\
\hline \multirow[t]{2}{*}{$\begin{array}{l}\text { 2. Collect. disease } \\
\text { eradication }\end{array}$} & $b e_{21}$ & $\begin{array}{l}\text {... will it contribute to the eradication of Bluetongue in the Netherlands } \\
\text { (at that moment) }\end{array}$ & 378 & 0.39 & 0.76 & $2.20(3.96)$ \\
\hline & $b e_{22}$ & ... will further spreading of Bluetongue be inhibited (at that moment) & 378 & 0.50 & & $3.25(3.93)$ \\
\hline \multirow[t]{2}{*}{ 3. Time and effort } & $b e_{31}$ & $\ldots$ will the amount of work involved with vaccination be little & 379 & -0.23 & 0.77 & $-2.06(4.56)$ \\
\hline & $b e_{32}$ & $\ldots$ will the preparation and performance of the vaccination take a lot of time ${ }^{a}$ & 379 & -0.21 & & $-1.96(4.26)$ \\
\hline \multirow[t]{2}{*}{ 4. Risk insurance } & $b e_{41}$ & $\begin{array}{l}\text {.. will the risk of getting economic damage from Bluetongue at my farm } \\
\text { be reduced }\end{array}$ & 378 & 0.59 & 0.32 & $4.69(3.97)$ \\
\hline & $b e_{42}$ & $\begin{array}{l}\text {... will the costs of vaccination be in the right proportion to the economic } \\
\text { risk from Bluetongue }\end{array}$ & 378 & $0.01^{\mathrm{c}}$ & & $1.87(3.83)$ \\
\hline \multirow[t]{2}{*}{ 5. Job satisfaction } & $b e_{51}$ & ... will be insured that I can continue working with a healthy herd & 379 & 0.55 & 0.66 & $4.52(3.24)$ \\
\hline & $b e_{52}$ & ... will possible harrowing disease cases in my herd be prevented & 379 & 0.42 & & $3.54(3.73)$ \\
\hline
\end{tabular}

a Those statements were negatively formulated and thus reversed.

b Each multiplicative composite was pair-wisely correlated with the average of the indicators representing the latent variable $A$.

c No significant correlation with $A$.

${ }^{\mathrm{d}}$ With Cronbach's alpha $\left(\alpha_{C}\right)$ the internal consistency reliability was measured for each pair of multiplicative composites representing an attribute.

Table 2

Description and some descriptive statistics of the injunctive normative referents identified.

\begin{tabular}{|c|c|c|c|c|c|c|}
\hline Referent & Ind. & $n$ & $n$ excl. $N A$ & $\% N A^{\mathrm{a}}$ & $\operatorname{corr}^{\mathrm{b}}$ & $M\left(S E_{M}\right)$ \\
\hline 1. Veterinarian & inm $_{1}$ & 363 & 345 & 5.0 & 0.38 & $5.87(3.45)$ \\
\hline 2. Study club members & $\mathrm{inm}_{2}$ & 361 & 187 & 48.2 & 0.28 & $1.19(2.64)$ \\
\hline 3. Exporter breeding cattle & $\mathrm{inm}_{3}$ & 364 & 186 & 48.9 & 0.16 & $3.08(4.34)$ \\
\hline 4. Animal welfare organization/society & $\mathrm{inm}_{4}$ & 364 & 255 & 29.9 & 0.36 & $2.51(3.07)$ \\
\hline 5. Contact bank/accountant & $\mathrm{inm}_{5}$ & 365 & 244 & 33.2 & 0.41 & $1.52(3.05)$ \\
\hline 6. Colleague dairy farmers & $\operatorname{inm}_{6}$ & 361 & 317 & 12.2 & 0.33 & $2.37(3.15)$ \\
\hline 7. Milk buyer & $\mathrm{inm}_{7}$ & 364 & 322 & 11.5 & 0.30 & $4.14(3.99)$ \\
\hline 8. Government representative & $\operatorname{inm}_{8}$ & 363 & 239 & 34.2 & 0.21 & $1.39(3.02)$ \\
\hline 9. Feed advisor & $\mathrm{inm}_{9}$ & 364 & 305 & 16.2 & 0.34 & $2.69(3.15)$ \\
\hline 10. Family and/or friends & $\mathrm{inm}_{10}$ & 365 & 282 & 22.7 & 0.39 & $1.53(3.04)$ \\
\hline 11. Leaders/representatives & inm $_{11}$ & 363 & 274 & 24.5 & 0.37 & $2.57(3.03)$ \\
\hline 12. Fellow believers & inm $_{12}$ & 367 & 170 & 53.7 & 0.28 & $0.56(2.52)$ \\
\hline
\end{tabular}

a Referents were included in the statistical analysis when less than $25 \%$ was a NA score.

b Each multiplicative composite was correlated with the average of the indicators representing the latent variable $N_{I}$.

Table 3

Description and some descriptive statistics of the descriptive normative referents identified.

\begin{tabular}{|c|c|c|c|c|c|c|}
\hline Referent & Ind. & $n$ & $n$ excl. NA & $\% N A^{\mathrm{a}}$ & corr $^{\mathrm{b}}$ & $M\left(S E_{M}\right)$ \\
\hline 1. Leaders/representatives & $d n i_{1}$ & 368 & 297 & 19.3 & 0.27 & $2.00(2.68)$ \\
\hline 2. Study club members & $d n i_{2}$ & 368 & 214 & 41.8 & 0.33 & $1.09(2.28)$ \\
\hline 3. Colleague dairy farmers & $d n i_{3}$ & 369 & 335 & 9.2 & 0.35 & $1.56(2.75)$ \\
\hline 4. Dairy farmers in the media & $\mathrm{dni}_{4}$ & 368 & 323 & 12.2 & 0.31 & $1.71(2.52)$ \\
\hline
\end{tabular}

a Referents were included in the statistical analysis when less than $25 \%$ was a NA score.

b Each multiplicative composite was correlated with the average of the indicators representing the latent variable $N_{I}$.

on the associated determinants of intention. To be able to include causal indicators, some form of formative instead of reflective measurement is needed. ${ }^{3}$ A suitable approach that allows for both forms of measurement is the multiple indicators and multiple causes (MIMIC) model (Jöreskog and Goldberger, 1975), which is the SEM equivalent for multiple regression.

Using MIMIC models, an index of multiplicative composites is analyzed as a set of causal indicators explaining a latent variable (Diamantopoulos and Winklhofer, 2001). The MIMIC model can be formally described as follows:

\footnotetext{
${ }^{3}$ For a background discussion on the distinction between effect and causal indicators, between formative and reflective measurement models and selection criteria, e.g. see Diamantopoulos and Winklhofer (2001), Jarvis et al. (2003) and Kline (2011)
}

$y=\Delta \eta+\epsilon$

$\eta=\Gamma x+\zeta$

where in Eq. (5) $y$ is a vector of effect indicators of latent variable $\eta$ (e.g. $A$ or $N I$ ), $\Delta$ a matrix of factor loadings and $\epsilon$ a vector of measurement error. ${ }^{4}$

In Eq. (6), $x$ (e.g. be $e_{1}$ or inm in $_{1}$ is a vector of causal indicators on $\eta$, $\Gamma$ a matrix of regression coefficients $\gamma$ 's of e.g. be $e_{1}$ or $i n m_{1}$ on its associated $\eta$, and $\zeta$ a vector of error terms. It is furthermore assumed that the $\varepsilon$ 's are uncorrelated with the $\zeta$ 's.

\footnotetext{
${ }^{4}$ Justification how this part is established and how the latent variables $\eta$ are represented, can be found in Sok et al. (2015).
} 
Table 4

Description and some descriptive statistics of the control beliefs identified.

\begin{tabular}{|c|c|c|c|c|c|c|}
\hline Control factors & Ind. & $\begin{array}{l}\text { Control belief statement } \\
\text { If a voluntary vaccination program was to be announced when Bluetongue } \\
\text { were to occur in my environment this year ... }\end{array}$ & $n$ & corr $^{\mathrm{b}}$ & $\alpha_{C}{ }^{d}$ & $M\left(S E_{M}\right)$ \\
\hline \multirow[t]{2}{*}{ 1. Communication } & $c p_{11}$ & $\begin{array}{l}\text {... will I receive sufficient information about the purposes and necessity of } \\
\text { preventive vaccination }\end{array}$ & 383 & 0.32 & 0.82 & $3.60(3.87)$ \\
\hline & $c p_{12}$ & ... will they give me a solid justification why preventive vaccination is required & 382 & 0.37 & & $4.03(3.58)$ \\
\hline \multirow[t]{2}{*}{ 2. Internal organization } & $c p_{21}$ & ... will vaccination be easy to perform on my farm & 382 & 0.27 & 0.02 & $3.81(3.91)$ \\
\hline & $c p_{22}$ & $\ldots$ will a vaccination round be difficult to organize at my farm ${ }^{a}$ & 383 & $-0.09^{\mathrm{c}}$ & & $1.14(4.70)$ \\
\hline \multirow[t]{2}{*}{ 3. Compensation } & $c p_{31}$ & ... will I have sufficient resources available to pay such an unforeseen expense & 382 & 0.24 & 0.78 & $3.05(3.94)$ \\
\hline & $c p_{32}$ & $\ldots$ will I not be able to cover the costs of preventive vaccination ${ }^{a}$ & 383 & 0.26 & & $2.80(4.28)$ \\
\hline \multirow[t]{2}{*}{ 4. Effectiveness } & $c p_{41}$ & $\ldots$ will it be clear to me how the available vaccine functions & 383 & 0.24 & 0.73 & $3.10(3.08)$ \\
\hline & $c p_{42}$ & ... will the available vaccine do what it needs to do, and nothing else & 380 & 0.38 & & $3.72(3.22)$ \\
\hline \multirow[t]{2}{*}{ 5. External organization } & $c p_{51}$ & ... will (government)organizations employ an efficient policy & 383 & 0.28 & 0.04 & $2.28(3.10)$ \\
\hline & $c p_{52}$ & $\ldots$ will the registering to join in the programme be laborious ${ }^{\mathrm{a}}$ & 383 & $-0.06^{\mathrm{c}}$ & & $1.70(4.16)$ \\
\hline
\end{tabular}

\footnotetext{
a Those statements were negatively formulated and thus reversed.

b Each multiplicative composite was pair-wisely correlated with the average of the indicators representing the latent variable $P B C$.

c No significant correlation with $P B C$.

d With Cronbach's alpha $\left(\alpha_{C}\right)$ the internal consistency reliability was measured for each pair of multiplicative composites representing an attribute.
}

\section{Data screening and preparation}

An initial screening of the data on missing values was made: 25 observations (6\%) were dropped because they had missing data on all indicators of all direct measures for $I, A, N_{I}, N_{D}$ and $P B C$. Next, in each model for the indirect measures, observations were dropped when they had missing data on all belief indicators and/or all outcome evaluations. This led to dropping 10 observations in the $b_{i j} e_{i j}$ section, 23 in the $i n_{k} m_{k}$ section, 21 in the $d n_{l} i_{l}$ section, and 5 in the $c_{m n} p_{m n}$ section.

For each attribute $i$, multiplicative composites were averaged if (1) both had a significant correlation with $A$ and (2) showed a high internal consistency reliability as measured by Cronbach's alpha $\left(\alpha_{C}\right)$.

The number of $N A$ ticks in the injunctive and descriptive normative section for a particular referent is understood as an indication of the importance of that referent in the sample for the behaviour under study. The NA option was not included in the continuous underlying distribution, as is often done by recoding $N A$ ticks to the middle tick of the Likert type scale. Instead, the number of $N A$ ticks were treated as a categorical and not continuous type of missing data and in this way functioned as a selection criterion to determine which referents to include in subsequent analyses. Only those referents were included in the analysis who had less than $25 \%$ NA ticks.

Since formative measurement is based on multiple regression, multicollinearity can be an issue (Diamantopoulos and Winklhofer, 2001). Kline (2011) indicates that a variance inflation factor (VIF) of $>10$ is indicating that variables may be redundant. The highest VIF was found in the linear regression of 'Effectiveness' on all other control factors, which was 3.14. It is concluded that there is mild collinearity among the control factors but not up to a level that is considered problematic. For the remaining determinants of intention there was only negligible to weak collinearity.

\section{Model assessment}

Assuming that the (composite) scales reflect continuous underlying distributions, maximum likelihood (ML) estimation is used, which is the default SEM estimation method.

Overall model fit of the MIMIC models is assessed first with the default $\chi^{2}$ test statistic. The null hypothesis tested here is that the sample covariance matrices equal the hypothesized covariance matrices. This test only shows whether the model is consistent with the data. Three commonly used approximate fit indexes were used to test whether the model was also correctly specified: the Steiger-Lind root mean square error of approximation (RMSEA) which is a parsimony-corrected index, the Bentler Comparative Fit Index (CFI) which is an incremental fit index, and the Standardized Root Mean Square Residual (SRMR) which is an absolute fit index, a statistic related to the covariance residuals (Hair et al., 2010; Kline, 2011). Overall model fit was further examined by inspecting (1) the matrix of standardized covariance residuals, which shows any difficulties the model has with fitting covariances, and (2) the modification indexes, which give suggestions for model improvement by freeing any single relationship that is not currently estimated.

The MIMIC model with referents $l$ causing ND failed some identification rules, specifically the $t$ rule and the $2+$ emitted path rule (Bollen and Davis, 2009). Therefore, a global reflectively-measured latent variable was included to overcome the identification problems and allowing overall model fit assessment (Diamantopoulos et al., 2008). The intention construct, represented by three indicators, was added to this model.

Once the overall model fit was assured, the impact of causal indicators on the associated determinants of intention was studied by looking at the direction and magnitude of the regression coefficients ( $\gamma$-parameters). Following the approach of Diamantopoulos and Winklhofer (2001) in estimating the MIMIC model, nonsignificant indicators that exceeded the $10 \%$ critical significance level were removed one at a time in an iterative process, starting with the indicators that had the lowest $t$-value.

\section{Results}

\section{Measured beliefs}

The causal indicators for each determinant of intention - $A, N I, N D$ and $P B C$ - are presented in Tables 1-4 respectively. An indicator is a multiplicative composite consisting of a belief statement with its associated outcome evaluation statement. Descriptive statistics of each indicator (ind.) are given in the tables, namely the number of observations ( $n$ ), correlation (corr) with the associated determinant of intention and the mean $(M)$ and standard error of the mean $\left(S E_{M}\right)$.

In the model for $A$ (Table 1 ), attributes are represented by the average of two associated indicators. Some attributes were only represented by one indicator, because of low internal consistency (measured with $\alpha_{C}$ ) and weakly correlated statements (see Section 'Data screening and preparation'). This happened often in case the statements were negatively formulated. A similar approach was used for control factors in the model for PBC (Table 4).

In the models for $N I$ and $N D$ (Tables 2 and 3 respectively), two columns were added with the number of observations excluding $N A$ scores ( $n$ excl. NA) and the ratio between the columns $n$ and 
$n$ excl. NA, expressed in a percentage (\% excl. NA). This column was generated to decide which referents to include (see Section 'Data screening and preparation').

All correlations between the attributes, referents and control factors and their belonging constructs had the a priori expected sign, e.g. the attribute 'Time and effort' is negatively correlated with $A$ and the control factor 'Effectiveness' is positively correlated with $P B C$.

\section{Behavioural outcomes for attitude}

Attitudinal beliefs identified from the semi-qualitative interview sessions were grouped into five attributes. These were a mix of instrumental (economic) and experiential (affective) attributes. The attribute which obtained the highest mean rank score was 'Risk insurance', to be insured against economic damage of BT. Other attributes with mainly instrumental economic orientations in order of mean rank score were 'Collective disease eradication', the individual contribution to support controlling the spread of BT; and 'Time and effort', the time and effort needed to prepare and perform the vaccination.

The orientation between instrumental and experiential was less clear-cut for 'Production distortions'. On the one hand, this attribute could be economically-oriented in terms of a loss of technical performance and thereby efficiency losses. On the other hand it could be experientially-oriented, as something farmers do not want to be confronted with having cows in bad health after vaccination against BT. The latter related to the experientially-oriented attribute 'Job satisfaction', which was mean ranked second highest. Most of the farmers interviewed indicated they did not want to be emotionally confronted with cows seriously suffering from the consequences of BT.

\section{Normative referents for perceived norms}

For the perceived norm construct, a distinction was made between injunctive norms $\left(N_{I}\right)$ and descriptive norms $\left(N_{D}\right)$. A total of 13 salient referents were identified from the interview sessions. Three referents were both classified as injunctive as well as descriptive norms. For example, a farmer (the respondent) has a perception of what fellow dairy farmers think he or she should do but at the same time takes into account the perceived behaviour of these fellow dairy farmers.

Regarding respondents' injunctive referents, six out of the twelve selected referents had less than 25\% NA ticks (underlined in Table 2). The 'Veterinarian' was the most important referent with 5\% NA ticks and the highest mean rank score. In order of mean rank score, the other referents selected were 'Milk buyer', 'Fellow dairy farmers', 'Feed advisor', 'Leaders/representatives' and 'Family and/or friends'.

Regarding respondents' descriptive referents, three out of the four selected referents had less than 25\% NA ticks (underlined in Table 3). 'Colleague dairy farmers', was the most important referent with about $9 \%$ NA ticks. The other referents selected were 'Lea ders/representatives' and 'Dairy farmers in the media'. All three selected referents had fairly low comparable mean rank scores.

\section{Control factors for perceived behavioural control}

The control beliefs identified from the semi-qualitative interview sessions were grouped into five control factors encompassing four external and one internal. The external control factor which obtained the highest mean rank score was 'Communication', i.e. the provision of reliable information that can be trusted. Other external control factors in order of mean rank score were 'Effectiveness', mainly the effectiveness of the vaccine (strategy); 'Compensation', not only to lower costs of vaccination but also as a signal of seriousness; and 'External organization', particularly the red tape. The internal control factor was 'Internal organization', the easiness with which vaccination could be performed at the farm, e.g. to lock up the cows by the feeding fence.
Table 5

Estimates of the various MIMIC models.

\begin{tabular}{|c|c|c|c|c|c|}
\hline \multirow[t]{2}{*}{ Cause } & \multicolumn{4}{|c|}{ Causal effect of $\gamma$ on... } & \multirow[t]{2}{*}{$p$} \\
\hline & $\eta_{A}$ & $\eta_{N I}$ & $\eta_{N D}$ & $\eta_{P B C}$ & \\
\hline$\gamma_{b e 1}$ & -.105 & & & & .012 \\
\hline$\gamma_{b e 2}$ & .218 & & & & .000 \\
\hline$\gamma_{b e 3}$ & -.093 & & & & .027 \\
\hline$\gamma_{b e 4}$ & .341 & & & & .000 \\
\hline$\gamma_{b e 5}$ & .277 & & & & .000 \\
\hline$\gamma_{\text {inm } 1}$ & & .209 & & & .001 \\
\hline$\gamma_{\text {inm } 6}$ & & .174 & & & .005 \\
\hline$\gamma_{\text {inm } 7}$ & & .113 & & & .075 \\
\hline$\gamma_{i n m 10}$ & & .222 & & & .000 \\
\hline$\gamma_{\text {inm } 11}$ & & .158 & & & .014 \\
\hline$\gamma_{d n i 1}$ & & & .176 & & .010 \\
\hline$\gamma_{d n i 3}$ & & & .308 & & .000 \\
\hline$\gamma_{d n i 4}$ & & & .179 & & .012 \\
\hline$\gamma_{c p 1}$ & & & & .239 & .004 \\
\hline$\gamma_{c p 4}$ & & & & .210 & .010 \\
\hline$N$ & 362 & 244 & 287 & 373 & \\
\hline$\chi^{2}$ & 20.52 & 17.37 & 23.57 & 5.60 & \\
\hline df & 16 & 10 & 11 & 1 & \\
\hline$p<$ & .198 & .067 & .015 & .018 & \\
\hline RMSEA & .028 & .055 & .063 & .111 & \\
\hline SRMR & .016 & .025 & .049 & .008 & \\
\hline CFI & .996 & .982 & .987 & .988 & \\
\hline
\end{tabular}

\section{MIMIC models}

Fig. 2 illustrates the MIMIC model using the results for the attributes $b e_{i}$ causing $A$. Table 5 presents the overall model fit indexes and the relative importance of the causal effects on the associated determinant of intention.

Based on the guidelines for establishing (un)acceptable fit provided by Hair et al. (2010), the model with attributes $b e_{i}$ causing $A$ had an excellent fit. The attributes together explained 54\% of the variance in $A$. The model with referents $k$ causing NI had a good fit; here the referents explained $36 \%$ of the variance in NI. Also, the model with referents $l$ causing $N D$ had a good fit as the referents selected explained $27 \%$ of the variance in $N D$. The overall model fit indices evaluated a model in which a global reflectively-measured latent variable was included for identification purposes (see Section 'Model assessment').

The model with control factors $c p_{m}$ causing $P B C$ showed a good fit, even though the RMSEA was only 0.111 . However, the RMSEA falsely indicates a poor fit since the $d f$ was only 1 (Kenny et al., 2014). Poor fit can be diagnosed by specifying additional models that include deleted parameters. With the non-significant control factors included to increase the $d f$, the model fit was as follows: $\chi^{2}=7.13$ with $d f=4, \quad p<.129 ; \quad$ RMSEA $=.046 ; \quad$ SRMR = .007; $\mathrm{CFI}=0.991$. In both model specifications, the control factors explained $18 \%$ of the variance in $P B C$.

Results reported no influential standardized covariance residuals. A few weak influential modification indices were reported suggesting omitted paths between a cause and one particular reflective indicator. For example, in the model with referents $k$ causing NI, there were two suggested omitted paths from the referents 'Veterinarian' and 'Leaders/representatives' to a particular reflective indicator of $\mathrm{NI}$ that was formulated as: [...] people in the industry whose opinions I value [...]. Therefore, the suggested omitted paths can be theoretically explained as both referents are people from the industry. However, there is no further justification for the inclusion of these paths. The causal effect is estimated via paths from both referents to the latent construct NI.

Focussing on the relative importance of the causal effects on the associated determinant of intention, all parameters that were statistically significant had the expected sign (see Table 5). 


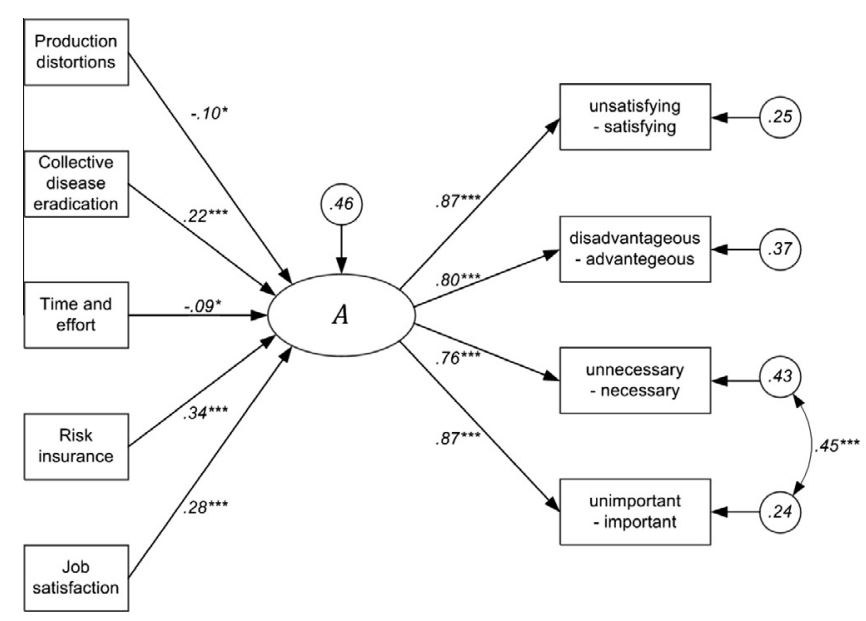

Fig. 2. An illustration of the MIMIC model with attributes $b e_{i}$ causing $A$.

Regarding the model with attributes $b e_{i}$ causing $A$, 'Risk insurance' obtained the highest $\gamma$-parameter, followed by 'Job satisfaction' and 'Collective disease eradication'. Although significant at the $5 \%$ critical level, the negative coefficients of 'Production distortions' and 'Time and effort' were low. Thus, the most influential attitudinal belief underlying the evaluation to perform preventive vaccination against BT was to be insured against the economic damage of the disease. Yet another influential underlying attitudinal belief was the 'psychological insurance' against the chance of facing harrowing disease cases and to be emotionally confronted with cows seriously suffering from the consequences of BT. The third in the order of influential beliefs was that with preventive vaccination a contribution is made to the eradication of the disease.

Regarding the model with referents $k$ causing $N_{I}$, 'Family and/or friends' obtained the highest $\gamma$-parameter, immediately followed by 'Veterinarian'. The third in order of influential injunctive referents was 'Colleague dairy farmers'. Thus, the most influential referents underlying the respondents' perceived injunctive norms are relatives and the veterinarian. It should be noted here that although almost equal in relative importance, the 'Veterinarian' was the most important and highest mean ranked referent compared to the other injunctive referents. ${ }^{5}$ Regarding the model with referents $l$ causing $N_{D}$, 'Colleague dairy farmers' obtained the highest $\gamma$-parameter, followed by 'Leaders/representatives' and 'Dairy farmers in the media'. Thus, the most influential referent underlying the respondents' perceived descriptive norms are 'Fellow dairy farmers'.

Regarding the model with control factors $c p_{m}$ causing $P B C$, 'Communication' obtained the highest $\gamma$-parameter, immediately followed by 'Effectiveness', both external control factors. Thus, the most influential control belief underlying the respondents' perceived own capability to perform the behaviour had to do with the communication of the responsible institutions to the farmers related to the justification and the necessity of preventive vaccination. Yet another influential underlying control belief related to the effectiveness of the vaccine (strategy).

\section{Discussion}

According to Fishbein and Ajzen (1975, 2010), beliefs are subjective probabilities, and they can be established in three different

\footnotetext{
${ }^{5}$ Different model specifications were run to check the robustness of the coefficients. A model specification with $\mathrm{inm}_{1}$ and $\mathrm{inm}_{10}$ in the index gave the following coefficients: $\gamma_{i n m 1}=.320$ and $\gamma_{i n m 10}=.304$ with $n=274$. A model specification with only inm $m_{1}$ gave the following coefficient: $\gamma_{i n m 1}=.412$ with $n=343$. A model specification with only $i_{n m}$ gave the following coefficient: $\gamma_{i n m 10}=.434$ with $n=280$. From the different model specifications it can be concluded that the two referents stay equally important.
}

ways: via (1) descriptive belief formation, which results from direct observation; (2) informational belief formation, which results from accepting information from some outside source; or (3) inferential belief formation, which results from a process of inference from some other belief.

Attitudinal beliefs about attributes can be classified into instrumental (economic) and experiential (affective) aspects of attitude (Fishbein and Ajzen, 2010). Thus, for the influential attitudinal beliefs found in this study, 'Risk insurance' and 'Collective disease eradication' are instrumental and 'Job satisfaction' is experiential in nature. Especially for the instrumental attributes, a more favourable attitude can be stimulated through information belief formation, a careful use of the communication intervention as a policy instrument to demonstrate the exposure to the potential risks of no vaccination at the farm but also country-wide. The significance of communication is confirmed as it was one of the influential external control factors ('Communication'). As this information needs to be 'accepted from an outside source', the selected risk communication channels through which information is sent matter. As Garforth et al. (2004: p. 28) observed: 'local and personal contacts generally have more influence on farmers' intentions than more distant and impersonal sources'.

Trust and credibility determine the success in changing attitudinal beliefs in risk communication. Information is more likely accepted if there is a credible communicator, a high level of 'similarity' between the audience and communicator and both the message and communicator must be perceived as trustworthy (Petty and Cacioppo, 1996). Trust and credibility are also crucial in the case of BT vaccination, particularly if farmers might have lost confidence in a publicly organized vaccination programme due to a contaminated vaccine offered in the past (Barkema et al., 2001; Elbers et al., 2010). The latter might provide an explanation of why the external control factor 'Effectiveness' is influential. Hence, all of the above justifies why in 2008 not only the Ministry itself but also farmer organizations recommended vaccination and farmer meetings were used to communicate.

Another policy instrument used in 2008 was subsidization of the costs of vaccination. From economic theory, it can be argued that when the probability of infection is high and expected economic consequences are large, vaccination provides a similar protection as insurance against the risk of infection. Farmers who perceive a high probability of infection without vaccination and expect large economic consequences of infection without vaccination will have a strong incentive to vaccinate. This was most likely the case in 2006 and 2007 for farmers in the southern and central part of the Netherlands, who experienced the negative effects of infection on their livestock (Schaik et al., 2008). In these circumstances, subsidization of vaccination might only have had a small effect on the motivation of a farmer to participate in a vaccination campaign (Sok et al., 2014). On the other hand, farmers in the northern part of the Netherlands might have perceived the risk of infection to be rather low in 2008, although in this area the largest proportion of susceptible animals was present. The 2008 vaccination plan indicated that 'special attention needs to be given to areas for which it is known that the Bluetongue seroprevalence is relatively low' (Ministry of Economic Affairs, 2008: p. 6). Hence, subsidization was used to provide an economic incentive to farmers in low prevalence areas to vaccinate. Moreover, providing subsidies (as opposed to fines) might also have served as an indicator of the seriousness with which the government was taking her responsibility, and therefore could well have been a complement to the communicative intervention that aims at motivating farmers intrinsically.

A key assumption in RAA is that beliefs do not have to be rational, nor have to be instinctive or stable over time. They are formed in daily encounters in the real world (Fishbein and Ajzen, 2010). The 
only assumption made in the RAA is that one's behaviour follows reasonably from beliefs. Therefore, it is very likely that the direct or indirect experiences with the consequences of the BT epidemic of 2006-2009 are captured within attitudinal beliefs through descriptive and/or inferential belief formation. In other words, farmers might have been basing their responses on their direct and indirect experiences with BT when filling in the questionnaire. Diverging BT experiences from the past could have led to a different set of influential attitudinal beliefs for different groups. Farmers in the southern part might have been more concerned with 'Production distortions' than farmers in the northern part of the Netherlands, because the BT prevalence was the highest in the southern part, where the outbreak started, and decreased towards the north (Elbers et al., 2008; Schaik et al., 2008). Furthermore, Elbers et al. (2010) reported that the probability of BT vaccine uptake in 2009 increased if farmers had experienced BT in the preceding years. This is in line with the assertion of RAA that beliefs are not necessarily rational. From a rational point of view, vaccination is less profitable if the herd has become immune through natural infection. Thus, some farmers might base, for a major part, their vaccination decisions on direct and indirect experiences with animal diseases no matter whether that decision is rational or not. Personal characteristics, such as the individuals' goals, values or conscientiousness can address these decisions (Austin et al., 2001; Willock et al., 1999). It can provide explanations why attitudinal beliefs are not always instrumental but can also be experientially-oriented, like the case of 'Job satisfaction' is showing (Gasson, 1973). Such contextual and personal factors can be used to address heterogeneity in beliefs among farmers.

The most influential normative beliefs found in this study were 'Family and friends' and 'Veterinarian', followed by 'Colleague dairy farmers'. The way these beliefs are formed is not exclusive, in fact, all three different ways of belief formation may be true. The multiplicative composite of 'Family and friends' (see Appendix A) consisted of a low belief score (0.44) and a moderate outcome evaluation score (2.80). Thus, the influence of relatives is not so much determined by a strong opinion relatives hold in favour of the behaviour under study, rather the normative influence itself is more important. This likely relates to the fact that Dutch dairy farms usually are family businesses; factors such as the case of multiple decision-makers, the stage in the family cycle and the dependence of family income from farm operations are taken into account in the decision-making process (Burton, 2006; Gasson et al., 1988).

The multiplicative composite of 'Veterinarian' (see Appendix A) consisted of a highly positive belief score (1.41) and a high outcome evaluation score (4.01). Thus, most farmers perceive the veterinarian's opinion to be in favour of vaccination while this normative belief is also important. This finding is in line with previous research showing that the veterinarian is being perceived as a highly trusted and influential referent in herd health management (e.g. Derks et al., 2013; Ellis-Iversen et al., 2010; Fisher, 2013; Kristensen and Jakobsen, 2011; Lam et al., 2011). This suggests that for future BT alike vaccination strategies, the social interactions between veterinarians and farmers might be an appropriate communication channel to use.

'Fellow dairy farmers' was the third in order of important injunctive normative beliefs, while being the most important descriptive normative belief. In both cases, the belief score was barely positive ( 0.60 and 0.42 respectively) and the outcome evaluation score moderate (3.30 and 2.96 respectively) (see Appendix A). The low scores might indicate that farmers had difficulties with forming a belief about (estimating a probability) and evaluating the outcome of normative influences from fellow dairy farmers for a hypothetical reactive vaccination scheme. Nevertheless, the fact that fellow dairy farmers are an influential referent in both type of norms suggests that social interactions among farmers about vaccination decisions exist. In case these social interactions are confidence-based, the belief can be formed through either descriptive (direct observation) or informational belief formation (accepting information). If there is more distance, the belief can be formed through inferential belief formation. Farmers may base their inferences on prior descriptive beliefs, such as beliefs concerning a colleague dairy farmer's personality or his or her farming style.

The preceding illustrates the complexity of understanding collective voluntary vaccination. Eradication programmes have characteristics of collectively produced goods (Oude Lansink, 2011), i.e. the success of eradication programmes depends on the success of collective action, while for an economic rational decision maker, the positive externality of a reduced likelihood of infection for colleague farmers is not an incentive to vaccinate (Rat-Aspert and Fourichon, 2010; Sok et al., 2014). This view, where each individual farmer is expected to behave autonomously and selfinterested, might be an "undersocialized" view (Granovetter, 1985); collective voluntary behaviour is also likely driven by social interactions within a community or network of farmers. In the latter, behavioural 'rules' that influence the collective outcome are e.g. norms of reciprocity, reputation, group identity, solidarity and trust, which are all elements of (informal) social capital (see e.g. Burton et al., 2008; Mathijs, 2003; Sutherland and Burton, 2011).

Peer group pressure is also indicated to be a policy instrument that can externally motivate voluntary behaviour (Van Woerkum, 1990). As this research has shown that social interaction among farmers exist, future research is needed to study more deeply the underlying mechanisms of social interactions that influence farmers' decision-making with regard to private and public interests of controlling future BT alike disease epidemics.

\section{Conclusions}

In the 2008 vaccination strategy against Bluetongue, the policy instruments used largely fitted in with the influential beliefs of dairy farmers that drove the intention to participate in a voluntary vaccination scheme.

The analysis of the beliefs shows that for a communication intervention, the communication channels used need to be credible and trusted by farmers. As farmers seem to already have intrinsic motivations to vaccinate, subsidization can complement a communication intervention to stress the seriousness with which the government takes her responsibility.

Given that social interactions among farmers about vaccination decisions exist, social interaction mechanisms, such as peer group pressure, might take the role of a 'catalyst' among the mix of policy instruments used in voluntary vaccination strategies.

\section{Acknowledgments}

This research was funded by the Ministry of Economic Affairs (Netherlands Food and Consumer Products Safety Authority) of the Netherlands via EMIDA ERA-NET "Coordination of European Research on Emerging and Major Infectious Diseases of Livestock" (funded by the European Commission's Seventh Framework Programme, Project No. 219235).

The authors would like to thank two anonymous reviewers for their valuable comments.

\section{Appendix A}

See Tables 6-9. 
Table 6

Rank scores and some descriptive statistics of the attitudinal beliefs $\left(b_{i j}\right)$ and outcome evaluations $\left(e_{i j}\right)$.

\begin{tabular}{|c|c|c|c|c|c|c|c|c|c|c|c|c|c|c|c|}
\hline \multicolumn{8}{|c|}{ Not likely $\gg$ Very likely } & \multicolumn{8}{|c|}{ Of no importance $<>$ Of importance } \\
\hline Ind. & 1 & 2 & 3 & 4 & 5 & Obs. & Mean $\left(S E_{M}\right)$ & Ind. & -2 & -1 & 0 & 1 & 2 & Obs. & Mean $\left(S E_{M}\right)$ \\
\hline$b_{11}$ & 26 & 83 & 111 & 95 & 63 & 378 & $3.22(1.17)$ & $e_{11}$ & 34 & 53 & 70 & 139 & 83 & 379 & $.49(1.23)$ \\
\hline$b_{12}$ & 20 & 60 & 125 & 108 & 66 & 379 & $3.37(1.10)$ & $e_{12}$ & 18 & 38 & 76 & 154 & 92 & 378 & .70 (1.09) \\
\hline$b_{21}$ & 40 & 67 & 82 & 139 & 51 & 379 & $3.25(1.20)$ & $e_{21}$ & 29 & 43 & 85 & 157 & 65 & 379 & $.49(1.13)$ \\
\hline$b_{22}$ & 25 & 25 & 80 & 174 & 75 & 379 & 3.66 (1.07) & $e_{22}$ & 18 & 28 & 79 & 167 & 87 & 379 & $.73(1.04)$ \\
\hline$b_{31}$ & 17 & 55 & 100 & 137 & 70 & 379 & $3.50(1.09)$ & $e_{31}$ & 89 & 101 & 96 & 65 & 29 & 380 & $-.41(1.23)$ \\
\hline$b_{32}$ & 33 & 60 & 111 & 122 & 53 & 379 & $3.27(1.15)$ & $e_{32}$ & 88 & 95 & 106 & 66 & 25 & 380 & $-.41(1.20)$ \\
\hline$b_{41}$ & 14 & 26 & 63 & 169 & 107 & 379 & $3.87(1.02)$ & $e_{41}$ & 12 & 11 & 50 & 164 & 142 & 379 & $1.09(.95)$ \\
\hline$b_{42}$ & 40 & 64 & 152 & 93 & 30 & 379 & 3.02 (1.07) & $e_{42}$ & 24 & 34 & 87 & 132 & 102 & 379 & $.67(1.15)$ \\
\hline$b_{51}$ & 41 & 50 & 109 & 138 & 41 & 379 & $3.23(1.15)$ & $e_{51}$ & 7 & 3 & 49 & 140 & 181 & 380 & $1.28(.85)$ \\
\hline$b_{52}$ & 31 & 37 & 110 & 145 & 57 & 380 & $3.42(1.11)$ & $e_{52}$ & 11 & 15 & 85 & 153 & 115 & 379 & $.91(.97)$ \\
\hline
\end{tabular}

Table 7

Rank scores and some descriptive statistics of the attitudinal beliefs $\left(i n_{k}\right)$ and outcome evaluations $\left(m_{k}\right)$.

\begin{tabular}{|c|c|c|c|c|c|c|c|c|c|c|c|c|c|c|c|c|c|}
\hline \multicolumn{9}{|c|}{ Much against $<>$ Much in favour } & \multicolumn{9}{|c|}{ Not important $\gg$ Very important } \\
\hline Ind. & -2 & -1 & 0 & 1 & 2 & Obs. & $\%$ Obs. $N A$ & Mean $\left(S E_{M}\right)$ & Ind. & 1 & 2 & 3 & 4 & 5 & Obs. & $\%$ Obs. $N A$ & Mean $\left(S E_{M}\right)$ \\
\hline$i n_{1}$ & 1 & 0 & 41 & 117 & 188 & 364 & 4.7 & $1.41(.72)$ & $m_{1}$ & 15 & 14 & 52 & 153 & 128 & 366 & 1.1 & $4.01(1.01)$ \\
\hline $\mathrm{in}_{2}$ & 3 & 13 & 106 & 56 & 16 & 363 & 46.6 & $.36(.79)$ & $m_{2}$ & 50 & 41 & 75 & 36 & 9 & 362 & 41.7 & $2.59(1.15)$ \\
\hline $\mathrm{in}_{3}$ & 14 & 11 & 52 & 34 & 82 & 364 & 47.0 & $.82(1.25)$ & $m_{3}$ & 65 & 23 & 70 & 37 & 39 & 366 & 36.1 & $2.84(1.42)$ \\
\hline$i n_{4}$ & 10 & 10 & 75 & 83 & 89 & 363 & 25.6 & $.87(1.04)$ & $m_{4}$ & 97 & 63 & 86 & 38 & 19 & 366 & 17.2 & $2.40(1.23)$ \\
\hline$i n_{5}$ & 11 & 5 & 115 & 70 & 47 & 364 & 31.9 & $.55(.97)$ & $m_{5}$ & 104 & 55 & 88 & 37 & 17 & 366 & 17.8 & $2.36(1.23)$ \\
\hline$i n_{6}$ & 4 & 12 & 138 & 129 & 43 & 362 & 9.9 & $.60(.81)$ & $m_{6}$ & 40 & 33 & 104 & 116 & 49 & 365 & 6.3 & $3.30(1.18)$ \\
\hline$i n_{7}$ & 2 & 7 & 95 & 96 & 128 & 365 & 10.1 & $1.04(.91)$ & $m_{7}$ & 33 & 23 & 72 & 98 & 118 & 366 & 6.0 & $3.71(1.27)$ \\
\hline$i n_{8}$ & 11 & 12 & 113 & 52 & 60 & 362 & 31.5 & $.56(1.05)$ & $m_{8}$ & 97 & 53 & 88 & 39 & 21 & 365 & 18.4 & $2.44(1.26)$ \\
\hline$i n_{9}$ & 3 & 6 & 117 & 131 & 56 & 365 & 14.2 & $.74(.81)$ & $m_{9}$ & 51 & 33 & 109 & 111 & 33 & 365 & 7.7 & $3.12(1.19)$ \\
\hline$i n_{10}$ & 9 & 13 & 153 & 77 & 42 & 367 & 19.9 & $.44(.90)$ & $m_{10}$ & 73 & 40 & 120 & 64 & 29 & 365 & 10.7 & $2.80(1.24)$ \\
\hline$i n_{11}$ & 8 & 12 & 79 & 104 & 83 & 364 & 21.4 & $.85(.98)$ & $m_{11}$ & 79 & 53 & 96 & 58 & 22 & 364 & 15.4 & $2.65(1.25)$ \\
\hline$i n_{12}$ & 16 & 14 & 94 & 38 & 14 & 367 & 52.0 & $.11(.98)$ & $m_{12}$ & 109 & 25 & 65 & 11 & 8 & 367 & 40.6 & $2.01(1.16)$ \\
\hline
\end{tabular}

Table 8

Rank scores and some descriptive statistics of the attitudinal beliefs $\left(d n_{l}\right)$ and outcome evaluations $\left(i_{l}\right)$.

\begin{tabular}{|c|c|c|c|c|c|c|c|c|c|c|c|c|c|c|c|c|c|}
\hline \multicolumn{9}{|c|}{ Definitely will not $<>$ Definitely will } & \multicolumn{9}{|c|}{ Not important $\gg$ Very important } \\
\hline Ind. & -2 & -1 & 0 & 1 & 2 & Obs. & $\%$ Obs. $N A$ & Mean $\left(S E_{M}\right)$ & Ind. & 1 & 2 & 3 & 4 & 5 & Obs. & $\%$ Obs. $N A$ & Mean $\left(S E_{M}\right)$ \\
\hline$d n_{1}$ & 5 & 5 & 120 & 102 & 69 & 368 & 18.2 & $.75(.88)$ & $i_{1}$ & 114 & 66 & 81 & 59 & 13 & 369 & 9.8 & $2.37(1.23)$ \\
\hline$d n_{2}$ & 6 & 9 & 132 & 60 & 15 & 368 & 39.7 & $.31(.77)$ & $i_{2}$ & 80 & 35 & 72 & 45 & 6 & 368 & 35.3 & $2.42(1.20)$ \\
\hline$d n_{3}$ & 5 & 20 & 165 & 124 & 23 & 369 & 8.7 & $.42(.77)$ & $i_{3}$ & 74 & 40 & 93 & 111 & 32 & 369 & 5.1 & $2.96(1.28)$ \\
\hline$d n_{4}$ & 2 & 13 & 143 & 131 & 36 & 368 & 11.7 & $.57(.76)$ & $i_{4}$ & 99 & 66 & 110 & 55 & 13 & 369 & 9.8 & $2.47(1.17)$ \\
\hline
\end{tabular}

Table 9

Rank scores and some descriptive statistics of the attitudinal beliefs $\left(c_{m n}\right)$ and outcome evaluations $\left(p_{m n}\right)$.

\begin{tabular}{|c|c|c|c|c|c|c|c|c|c|c|c|c|c|c|c|}
\hline \multicolumn{8}{|c|}{ Not likely $\gg$ Very likely } & \multicolumn{8}{|c|}{ Harder/dissuading $<>$ Easier/persuading } \\
\hline Ind. & 1 & 2 & 3 & 4 & 5 & Obs. & Mean $\left(S E_{M}\right)$ & Ind. & -2 & -1 & 0 & 1 & 2 & Obs. & Mean $\left(S E_{M}\right)$ \\
\hline$c_{11}$ & 9 & 25 & 68 & 192 & 90 & 384 & $3.86(.93)$ & $p_{11}$ & 12 & 8 & 94 & 170 & 100 & 384 & $.88(.93)$ \\
\hline$c_{12}$ & 15 & 35 & 109 & 167 & 58 & 384 & $3.57(.98)$ & $p_{12}$ & 12 & 6 & 66 & 168 & 131 & 383 & $1.04(.93)$ \\
\hline$c_{21}$ & 7 & 17 & 60 & 183 & 117 & 384 & $4.01(.90)$ & $p_{21}$ & 9 & 12 & 90 & 175 & 97 & 383 & $.89(.90)$ \\
\hline$c_{22}$ & 8 & 19 & 65 & 134 & 159 & 385 & $4.08(.98)$ & $p_{22}$ & 28 & 41 & 160 & 103 & 51 & 383 & $.28(1.06)$ \\
\hline$c_{31}$ & 20 & 27 & 99 & 129 & 108 & 383 & $3.73(1.10)$ & $p_{31}$ & 15 & 17 & 112 & 155 & 85 & 384 & $.72(.98)$ \\
\hline$c_{32}$ & 17 & 16 & 99 & 101 & 150 & 383 & $3.92(1.10)$ & $p_{32}$ & 17 & 17 & 115 & 152 & 84 & 385 & $.70(1.00)$ \\
\hline$c_{41}$ & 40 & 71 & 117 & 108 & 49 & 385 & $3.14(1.17)$ & $p_{41}$ & 11 & 9 & 76 & 193 & 94 & 383 & $.91(.90)$ \\
\hline$c_{42}$ & 25 & 52 & 152 & 114 & 38 & 381 & $3.23(1.02)$ & $p_{42}$ & 8 & 6 & 71 & 157 & 142 & 384 & $1.09(.89)$ \\
\hline$c_{51}$ & 56 & 84 & 128 & 86 & 29 & 383 & $2.86(1.15)$ & $p_{51}$ & 20 & 16 & 106 & 161 & 82 & 385 & $.70(1.02)$ \\
\hline$c_{52}$ & 17 & 26 & 112 & 117 & 113 & 385 & $3.74(1.09)$ & $p_{52}$ & 18 & 36 & 148 & 117 & 64 & 383 & $.45(1.03)$ \\
\hline
\end{tabular}

\section{References}

Austin, E.J., Deary, I.J., Willock, J., 2001. Personality and intelligence as predictors of economic behaviour in Scottish farmers. Eur. J. Pers. 15, S123-S137.

Barkema, H.W., Bartels, C.J., van Wuijckhuise, L., Hesselink, J.W., Holzhauer, M., Weber, M.F., Franken, P., Kock, P.A., Bruschke, C.J., Zimmer, G.M., 2001. Outbreak of bovine virus diarrhea on Dutch dairy farms induced by a bovine herpesvirus
1 marker vaccine contaminated with bovine virus diarrhea virus type 2 . Tijdschr. Diergeneeskd. 126, 158-165.

Bollen, K.A., Davis, W.R., 2009. Causal indicator models: identification, estimation, and testing. Struct. Equ. Model.: Multidiscip. J. 16, 498-522.

Burton, R.J.F., 2006. An alternative to farmer age as an indicator of life-cycle stage: the case for a farm family age index. J. Rural Stud. 22, 485-492.

Burton, R.J.F., Kuczera, C., Schwarz, G., 2008. Exploring farmers' cultural resistance to voluntary agri-environmental schemes. Sociol. Ruralis 48, 16-37. 
Jarvis, Cheryl Burke, MacKenzie, Scott B., Podsakoff, Philip M., 2003. A critical review of construct indicators and measurement model misspecification in marketing and consumer research. J. Consum. Res. 30, 199-218.

de Koeijer, A., Boender, G., Nodelijk, G., Staubach, C., Meroc, E., Elbers, A., 2011. Quantitative analysis of transmission parameters for bluetongue virus serotype 8 in Western Europe in 2006. Vet. Res. 42, 53.

Derks, M., van Werven, T., Hogeveen, H., Kremer, W.D.J., 2013. Veterinary herd health management programs on dairy farms in the Netherlands: use, execution, and relations to farmer characteristics. J. Dairy Sci. 96, 1623-1637.

Diamantopoulos, A., Riefler, P., Roth, K.P., 2008. Advancing formative measurement models. J. Bus. Res. 61, 1203-1218.

Diamantopoulos, A., Winklhofer, H.M., 2001. Index construction with formative indicators: an alternative to scale development. J. Mark. Res. 38, 269-277.

Elbers, A.R., de Koeijer, A.A., Scolamacchia, F., van Rijn, P.A., 2010. Questionnaire survey about the motives of commercial livestock farmers and hobby holders to vaccinate their animals against Bluetongue virus serotype 8 in 2008-2009 in the Netherlands. Vaccine 28, 2473-2481.

Elbers, A.R., Popma, J., Oosterwolde, S., van Rijn, P.A., Vellema, P., van Rooij, E.M. 2008. A cross-sectional study to determine the seroprevalence of bluetongue virus serotype 8 in sheep and goats in 2006 and 2007 in the Netherlands. BMC Vet. Res. 4, 33.

Elbers, A.R.W., De Koeijer, A.A., Van Rijn, P.A., 2009. Beweegredenen van commerciële veehouders en hobbydierhouders om te vaccineren tegen Blauwtong tijdens een vrijwillige vaccinatiecampagne in 2008 en 2009 in Nederland. Centraal Veterinair Instituut, Lelystad, Wageningen UR (in Dutch).

Ellis-Iversen, J., Cook, A.J., Watson, E., Nielen, M., Larkin, L., Wooldridge, M. Hogeveen, H., 2010. Perceptions, circumstances and motivators that influence implementation of zoonotic control programs on cattle farms. Prev. Vet. Med. 93, 276-285.

Enticott, G., Maye, D., Fisher, R., Ilbery, B., Kirwan, J., 2014. Badger vaccination: dimensions of trust and confidence in the governance of animal disease. Environ. Plann. A 46, 2881-2897.

European Council, 2000. Directive 2000/75/EC laying down specific provisions for the control and eradication of bluetongue. Official Journal of the European Union 327, pp. 74-83.

European Council, 2007. Commission Regulation number 1266/2007 on implementation rules for Council Directive 2005/75/EC as regards the control, monitoring, surveillance and restrictions on movements of certain animals of susceptible species in relation to bluetongue. Official Journal of the European Union 283, pp. 37-52.

Feather, N.T., 1959. Subjective probability and decision under uncertainty. Psychol. Rev. 66, 150-164.

Fishbein, M., 1963. An investigation of the relationship between beliefs about an object and the attitude toward that object. Hum. Relat. 16, 233-239.

Fishbein, M., Ajzen, I., 1975. Belief, Attitude, Intention, and Behavior: An Introduction to Theory and Research. Addison-Wesley, Reading, MA.

Fishbein, M., Ajzen, I., 2010. Predicting and Changing Behavior: The Reasoned Action Approach. Psychology Press, New York.

Fisher, R., 2013. 'A gentleman's handshake': the role of social capital and trust in transforming information into usable knowledge. J. Rural Stud. 31, 13-22.

Francis, J.J., Johnston, M., Eccles, M.P., Grimshaw, J., Kaner, E.F.S., 2004. Appendix C: Discussion Paper. Measurement Issues in the Theory of Planned Behaviour, Constructing Questionnaires Based on the Theory of Planned Behaviour: A Manual for Health Service Researchers. Centre for Health Services Research, Newcastle Upon Tyne.

Furubotn, E.G., Richter, R., 1998. Institutions and Economic Theory: The Contribution of the New Institutional Economics. The University of Michigan Press, Ann Arbor.

Garforth, C., Rehman, T., McKemey, K., Tranter, R., Cooke, R., Yates, C., Park, J., Dorward, P., 2004. Improving the design of knowledge transfer strategies by understanding farmer attitudes and behaviour. J. Farm Manage. 12, 17-32.

Gasson, R., 1973. Goals and values of farmers. J. Agric. Econ. 24, 521-542.

Gasson, R., Crow, G., Errington, A., Hutson, J., Marsden, T., Winter, D.M., 1988. The farm as a family business: a review. J. Agric. Econ. 39, 1-41.
Granovetter, M., 1985. Economic action and social structure: the problem of embeddedness. Am. J. Sociol. 91, 481-510.

Hair, J.F., Black, W.C., Babin, B.J., Anderson, R.E., 2010. Multivariate Data Analysis, seventh ed. Prentice Hall, Englewood Cliffs, NJ.

IFAH, 2012. Bluetongue Factsheet. <http://www.ifaheurope.org/component/ attachments/attachments/313.html?task=download $>$.

Jöreskog, K.G., Goldberger, A.S., 1975. Estimation of a model with multiple indicators and multiple causes of a single latent variable. J. Am. Stat. Assoc. 70, 631-639.

Kenny, D.A., Kaniskan, B., McCoach, D.B., 2014. The performance of RMSEA in models with small degrees of freedom. Sociol. Methods Res., 1-22

Kline, R.B., 2011. Principles and Practice of Structural Equation Modeling, third ed. The Guilford Press, New York.

Kristensen, E., Jakobsen, E.B., 2011. Challenging the myth of the irrational dairy farmer; understanding decision-making related to herd health. N. Z. Vet. J. 59 (1), $1-7$.

Lam, T.J.G.M., Jansen, J., van den Borne, B.H.P., Renes, R.J., Hogeveen, H., 2011. What veterinarians need to know about communication to optimise their role as advisors on udder health in dairy herds. N. Z. Vet. J. 59, 8-15.

Mathijs, E., 2003. Social capital and farmers' willingness to adopt countryside stewardship schemes. Outlook Agric. 32, 13-16.

Maye, D., Enticott, G., Naylor, R., Ilbery, B., Kirwan, J., 2014. Animal disease and narratives of nature: Farmers' reactions to the neoliberal governance of bovine Tuberculosis. J. Rural Stud. 36, 401-410.

Ministry of Economic Affairs, 2008. Vaccinatieplan Blauwtong. <http://www. rijksoverheid.nl/documenten-en-publicaties/rapporten/2008/04/ 24/vaccinatieplan-blauwtong.html> (in Dutch).

Montaño, D.E., Kasprzyk, D., 2008. Theory of reasoned action, theory of planned behavior, and the integrated behavioral model. In: Glanz, K. Rimer, B.K. Viswanath, K. (Eds.), Health Behavior and Health Education: Theory, Research, and Practice, fourth ed. Jossey-Bass, San Francisco (Chapter 4).

OIE, 2014. OIE-Listed Diseases, Infections and Infestations in Force in 2014. <http:// www.oie.int/animal-health-in-the-world/oie-listed-diseases-2014/>.

Oude Lansink, A.G.J.M., 2011. Public and private roles in plant health management. Food Policy 36, 166-170.

Petty, R.E., Cacioppo, J.T., 1996. Attitudes and Persuasion: Classic and Contemporary Approaches. Westview Press.

Rat-Aspert, O., Fourichon, C., 2010. Modelling collective effectiveness of voluntary vaccination with and without incentives. Prev. Vet. Med. 93, 265-275.

Schaik, G.V., Berends, I.M.G.A., Langen, H.v., Elbers, A.R.W., Vellema, P., 2008. Seroprevalence of bluetongue serotype 8 in cattle in the Netherlands in spring 2007, and its consequences. Vet. Rec. 163, 441-444.

Sok, J., Hogeveen, H., Elbers, A.R.W., Velthuis, A.G.J., Oude Lansink, A.G.J.M., 2014 Expected utility of voluntary vaccination in the middle of an emergent Bluetongue virus serotype 8 epidemic: a decision analysis parameterized for Dutch circumstances. Prev. Vet. Med. 115, 75-87.

Sok, J., Hogeveen, H., Elbers, A.R.W., Oude Lansink, A.G.J.M., 2015. Using farmers' attitude and social pressure for designing voluntary Bluetongue vaccination strategies (submitted for publication).

Sutherland, L.-A., Burton, R.J.F., 2011. Good farmers, good neighbours? The role of cultural capital in social capital development in a Scottish farming community. Sociol. Ruralis 51, 238-255.

Van Woerkum, C.M.J., 1990. Het instrumentele nut van voorlichting in bedrijfsprocessen. (The instrumental value of extension in policy processes.). Massacommunicatie 18, 263-278.

Velthuis, A.G., Mourits, M.C., Saatkamp, H.W., de Koeijer, A.A., Elbers, A.R., 2011. Financial evaluation of different vaccination strategies for controlling the bluetongue virus serotype 8 epidemic in The Netherlands in 2008. PLoS One 6, e19612.

Willock, J., Deary, I.J., McGregor, M.M., Sutherland, A., Edwards-Jones, G., Morgan, O., Dent, B., Grieve, R., Gibson, G., Austin, E., 1999. Farmers' attitudes, objectives, behaviors, and personality traits: the Edinburgh study of decision making on farms. J. Vocat. Behav. 54, 5-36. 